\title{
Mantle-derived minerals thermobarometry: Lithosphere studies and diamond prospectivity of the Kola region (NW Russia)
}

\author{
Dmitry Zozulya ${ }^{1}$, Petri Peltonen ${ }^{2}$, Hugh O’Brien ${ }^{2}$ and Marja Lehtonen ${ }^{2}$ \\ ${ }^{1}$ Geological Institute, Kola Science Centre, Apatity, Russia; ${ }^{2}$ Geological Survey of Finland, Espoo,
} Finland

The Kola region of the eastern Fennoscandian shield is prospective for diamondiferous magmatism based on structural-tectonic conditions that include: confinement to a platform with a Precambrian basement, thick lithosphere (170-240 km), and low heat flow $(<40$ $\mathrm{mW} / \mathrm{m}^{2}$ ). The Kola region is located within the Kola and Karelian subcratons, which were amalgamated already by the Late Archean. Also critical for diamond prospectivity, kimberlitic magmatism has been recognized in the Kola region, occurring as abundant dykes and explosive pipes of alkaline and alkalineultrabasic composition (Fig. 1). Numerous kimberlitic indicator minerals and diamonds have been recovered from the Quaternary sediments of the region. Based on these discoveries, kimberlitic field are predicted in the Makeevka, Pyalitsa, Pulonga, Snezhnitsa fields in south-east Kola and the Zarechensk field in south-west Kola (Zozulya et al., 2007). Also prospective is the southern part of region where the two Ermakovsky low-grade kimberlitic pipes are located (Kalinkin et al., 1993).

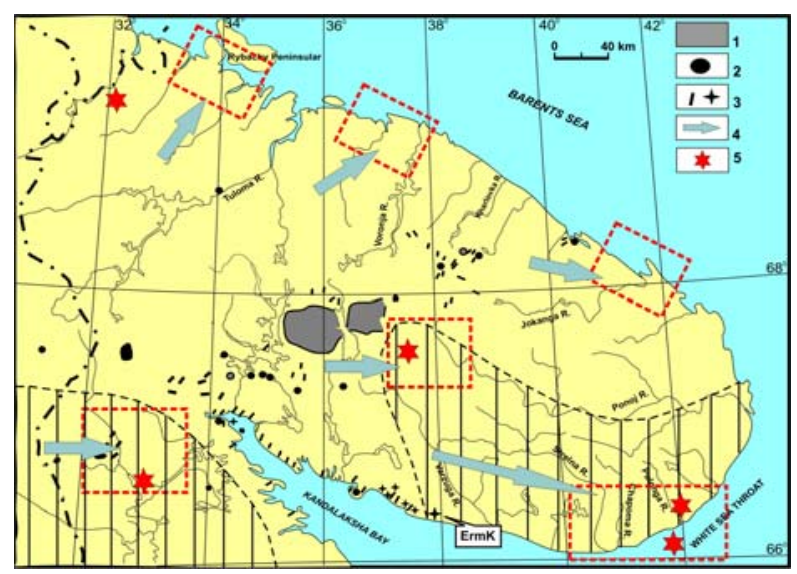

Fig. 1. Location of mantle-derived magmatic rocks in the Kola craton and the areas sampled (red boxes) from the south-eastern, south-western, central and northern parts of the region (1. nepheline syenites; 2 . alkaline-ultrabasic rocks and carbonatites; 3. alkaline-ultrabasic dikes and pipes (ErmK Ermakovsky kimberlitic pipe); 4. main transportation direction of Quaternary material by the Scandinavian icesheet; 5. diamond discoveries in Quarternary sediments). Striped areas on map are prospective for diamondiferous kimberlites based on this study.

More than 600 pyrope and chrome diopside grains recovered from Quaternary sediments (till, alluvium, coastal sediments) of the southern, central and northern parts of the Kola Craton (Fig. 1) were analyzed in order to determine their P-T parameters. Representing either mantle xenocrysts or constituents of mantle xenoliths, the pyropes and chrome diopsides contain valuable information on the composition of the lithospheric mantle and its thermal properties. It is established (Hirvas, 1977) that in the glaciated areas the main proportion (75-90\%) of the transported detrital material has local $(0-5 \mathrm{~km})$ rather than distal sources. This implies that the samples used in this study mostly represent locally derived materials. Indicator minerals in these sediments also include pyropes and diopsides from relatively shallow crustal eclogites and eclogitic xenoliths and xenocrysts from non-kimberlitic dykes and pipes.
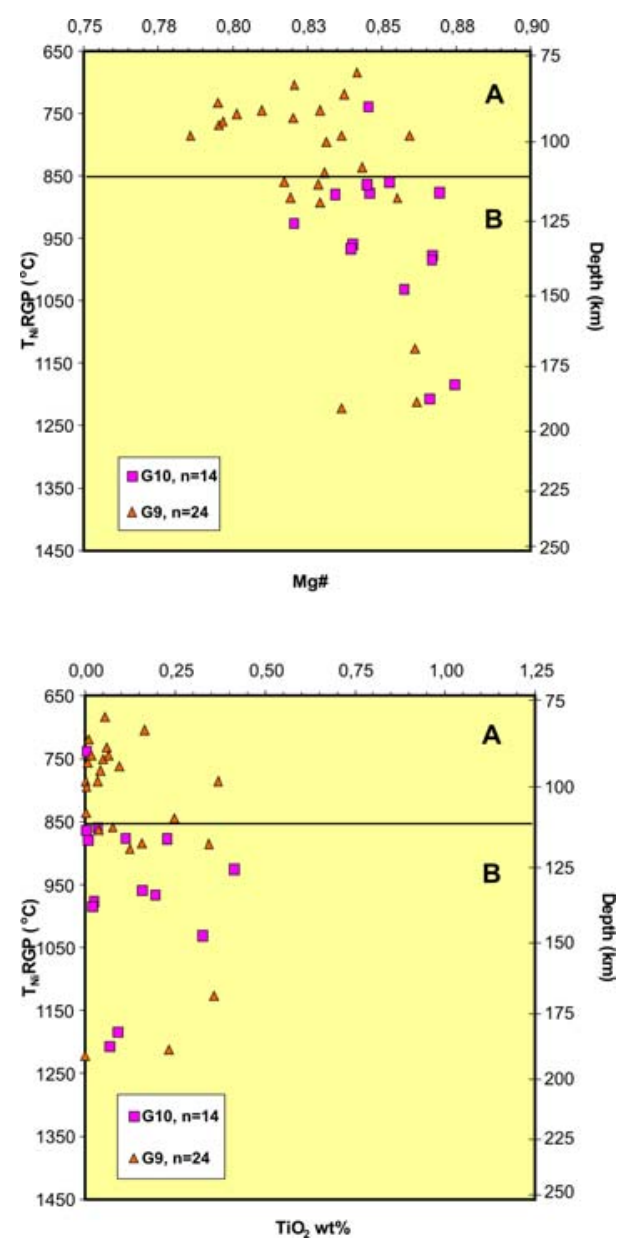

Fig. 2. Calculated temperature and depth versus $\mathrm{TiO}_{2}$ content and Mg\# for pyropes from south-eastern Kola region. 

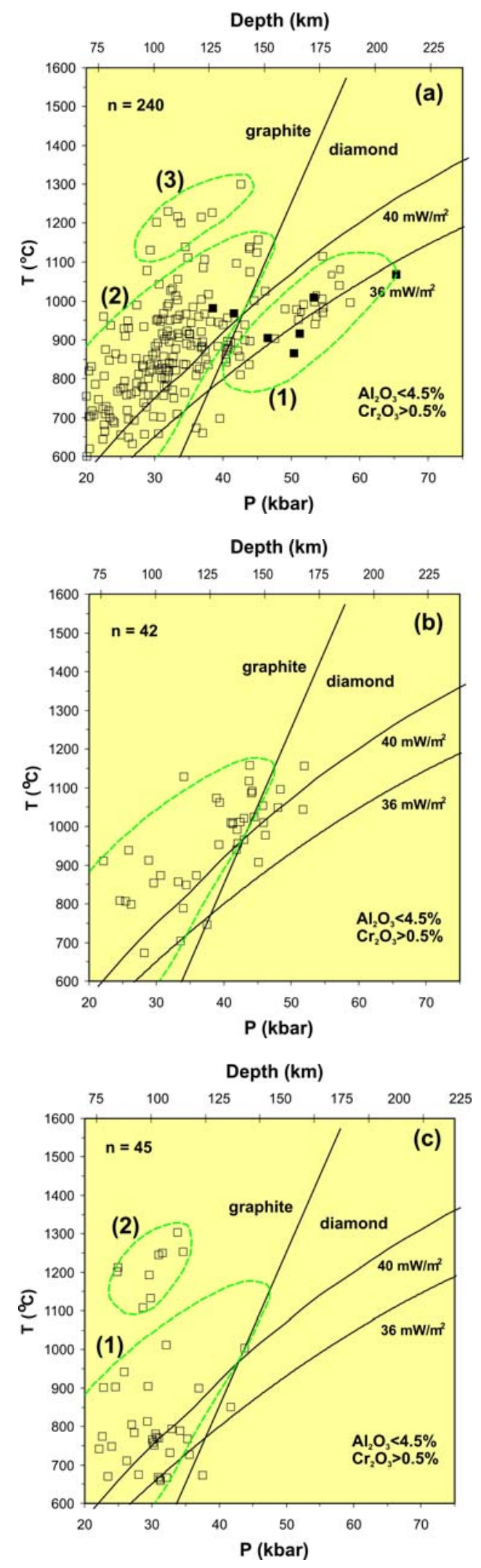

Fig. 3. Calculated P-T parameters for peridotitic chrome diopsides from the Quaternary sediments of the Kola region (a - south-eastern (open squares) and south-western (solid squares) parts; b - central part; c - northern part). PC model geotherm of Pollack \& Chapman (1977).
Consequently a thorough discrimination was made to exclude any grains not originally derived from deep lithospheric peridotites (G9 and G10 pyropes; chrome diopsides with $\mathrm{Al}_{2} \mathrm{O}_{3}<4.5$ wt.\%, $\mathrm{Cr}_{2} \mathrm{O}_{3}>0.5$ wt.\%, $\mathrm{Na}_{2} \mathrm{O}<2$ wt.\% and $\mathrm{MgO}>15$ wt.\%).

Ni-thermometry (Ryan et al., 1996) on pyropes from south-eastern Kola gives a range of temperatures between $650-1250^{\circ} \mathrm{C}$, corresponding to a sampling interval of ca. $75-190 \mathrm{~km}$ (Fig. 2). From the distribution of the different pyrope groups and their trace element compositions, a stratified structure to the southern Kola Craton lithospheric mantle is inferred: G10-pyropes are absent in the shallow mantle horizon (layer A: 75-110 km) which is the main source of G9pyropes, whereas a deeper mantle horizon between 110 and $190 \mathrm{~km}$ (layer B) has contributed abundant G10pyropes to the magmas. Overall, ca. $16 \%$ of the pyropes are derived from the stability field of diamond, i.e. from a depth of 140-190 km.

P-T determinations on peridotitic chrome diopsides using the single-grain thermobarometer of Nimis \& Taylor (2000) imply that the majority of grains from south-eastern Kola fall into the graphite stability field within $20-45 \mathrm{kbar}$ and $700-1300^{\circ} \mathrm{C}$ (Fig. 3a). These grains apparently originated from non-diamondiferous ultramafic xenoliths in alkaline-ultramafic dykes of the region. Nevertheless, ca. $15 \%$ of south-eastern Kola diopsides yield values of $40-60 \mathrm{kbar}$ and $700-1100^{\circ} \mathrm{C}$ and indicate derivation from the stability field of diamond. Diopsides from south-western Kola yield P-T estimates in the range of $45-65 \mathrm{kbar}$ and $850-1100^{\circ} \mathrm{C}$ (Fig. 3a), and dominantly plot in the diamond stability field. Diopsides from the central Kola yield P-T values of $20-55 \mathrm{kbar}$ and $700-1150^{\circ} \mathrm{C}$ (Fig. 3b), with ca. $20 \%$ derived from the diamond stable field. Diopsides from the northern Kola region, in contrast, yield P-T values of $20-45$ kbar and $600-1300^{\circ} \mathrm{C}$ (Fig. 3c), all falling within the stability field of graphite. The maximum depth of xenocryst sampling varies from up to $200 \mathrm{~km}$ in the southern Kola, to $170 \mathrm{~km}$ in central Kola, and only to $140 \mathrm{~km}$ in the northern Kola region.

The P-T values for chrome diopsides thus imply significant regional variations in the heat flow. Within the southern part of the Kola, adjacent to the Kandalaksha graben, the chrome diopside data (clusters 2 and 3 on Fig. 3a) plot between the 36 and $46 \mathrm{~mW} / \mathrm{m}^{2}$ model geotherms of Pollack \& Chapman (1977). Importantly, towards the east and towards the west, away from Kandalaksha graben, the lithosphere appears to become thicker and the heat flow corresponds to a cool cratonic model geotherm of 35$38 \mathrm{~mW} / \mathrm{m}^{2}$ (cluster 1 on Fig. 3a). The central Kola, in turn, is characterized by a more elevated heat flow of ca. $38-44 \mathrm{~mW} / \mathrm{m}^{2}$. The highest heat flow values (up to $50 \mathrm{~mW} / \mathrm{m}^{2}$, cluster 2 on Fig. 3c), are observed in the northernmost Kola Craton, adjacent to the Barents rift system. 
In summary, our data indicate that the more "cratonic" south-eastern, south-western and likely central parts of the Kola region have higher potential for diamondiferous kimberlitic magmatism than the northern part of the Kola Craton (Fig.1).

The study was supported by the Russian Fund for Basic Research (06-0564130) and by the Department of Earth Science RAS (Program 4).

Hirvas N., 1977. Glacial transport in Finnish Lapland. In: Prospecting in areas of glaciated terrain, pp. 128-137.

Kalinkin M.M, Arzamastzev A.A. \& Polyakov I.V., 1993, Kimberlites and related rocks of the Kola region. Petrology 1, 205-214.
Nimis P., Taylor W.R., 2000. Single clinopyroxene thermobarometry for garnet peridotites. Part I. Calibration and testing of a Cr-in-cpx barometer and an enstatitein-cpx thermometer. Contrib. Mineral. Petrol. 139, 541-554.

Pollack H.N., Chapman D.S., 1977. On the regional variations of heat flow, geotherms and lithosphere thickness. Tectonophysics 38, 279-296.

Ryan C.G., Griffin W.L., Pearson N.J., 1996. Garnet geotherms: Pressure-temperature data from Cr-pyrope garnet xenocrysts in volcanic rocks. J. Geophys. Res. 101, 5611-5625.

Zozulya D.R., Peltonen P., O’Brien H., 2007. Pyrope and chrome diopside as indicators of the mantle structure and diamond-bearing facies in Kola Region. Zapiski RMO (Proc. Russ. Mineral. Soc.) 136(4), 1-15. 